\title{
Financial Development and Economic Growth: Additional Evidence from Ghana
}

\author{
Grace Ofori-Abebrese1, Robert Becker Pickson ${ }^{2 *}$, Benjamin Tsatsu Diabah' \\ ${ }^{1}$ Department of Economics, Kwame Nkrumah University of Science and Technology, Kumasi, Ghana \\ ${ }^{2}$ College of Economics and Management, Sichuan Agricultural University, Chengdu, China \\ Email: *myselfpickson@yahoo.com
}

How to cite this paper: Ofori-Abebrese, G., Pickson, R.B. and Diabah, B.T. (2017) Financial Development and Economic Growth: Additional Evidence from Ghana. Modern Economy, 8, 282-297. https://doi.org/10.4236/me.2017.82020

Received: January 16, 2017

Accepted: February 21, 2017

Published: February 24, 2017

Copyright (c) 2017 by authors and Scientific Research Publishing Inc. This work is licensed under the Creative Commons Attribution International License (CC BY 4.0).

http://creativecommons.org/licenses/by/4.0/

Open Access

\begin{abstract}
Although the finance-growth relationship has been looked at in many African countries such as Ghana, the outcomes have been mixed while the causal direction between the two variables has particularly not been examined. This study, therefore, applied ARDL approach and Granger causality test to investigating the relationship and the causal direction between financial development and economic growth in Ghana during the period 1970-2013. The study revealed that the amount of credit from domestic sources to the private sector maintained a positively significant nexus with the growth of the economy whereas the domestic deposit was not the case. Also, the results established that there is a dependence of the Ghanaian economy to the changes in domestic credit to private sector whilst there exists a uni-directional causality running from the variations in economic growth to the domestic deposit in Ghana. Consistent with the findings, it is recommended that the authorities concentrate on improving the efficiency of the financial system to allow deposits to be channelled to growth-inducing investments to bring about the long-term growth of the economy.
\end{abstract}

\section{Keywords}

Financial Development, Economic Growth, ARDL, Granger Causality, Ghana

\section{Introduction}

The finance-growth nexus is not foreign to the literature in economics. Schumpeter [1] cited in Levine [2] argued that when the financial system of a country functions properly, it can stimulate economic growth by encouraging innovations in technology and by identifying individuals who stand the greatest chance of succeeding at implementing novel products and manufacturing methods. Subsequently, McKinnon [3] and Shaw [4] added that when state officials inter- 
fere with a country's financial structure by way of ceilings on rate of interest, high reserve conditions, and credit control programmes, it impedes the development of the financial sector, thereby sacrificing higher rates of growth of the economy. For example, La Porta et al. [5] demonstrated that excessive ownership of banks by the state lowers bank development while slowing economic growth, mostly in developing countries. Therefore, McKinnon [3] and Shaw [4] emphasized liberalisation of the financial sector as crucial in promoting the growth of the economy.

Accordingly, from the 1970s, developing economies began to look favourably on financial liberalisation as an important way to improve the financial sector as well as the growth of the economy. Specifically for Ghana, the Financial Sector Adjustment Programme (FINSAP) was adopted in 1988 as part of a comprehensive economic reform programme (Economic Recovery Programme) initiated by International Monetary Fund (IMF) and the World Bank (WB), with the goal of liberalizing the financial system to help overcome the problems (e.g. shallow financial system, decreased savings and private investment, and low economic growth) created by the repressive policies (e.g. ceilings on rates of interest and capital controls) of the 1960s to the mid-1980s (Aryeetey et al. [6]). Chief among the reform measures were restructuring of state-owned banks, commencement of structural reform (e.g. fiscal and monetary operations), allowing private participation, eliminating credit controls, as well as developing short-term and long-term financial markets (Bawumia, [7]). Subsequent to FINSAP, the Financial Sector Strategic Plan (FINSSP) was implemented from 2001 to further develop the financial system of the country (ibid).

Results from both the FINSAP and FINSSP seem to show some recovery in the financial sector and growth of the economy. The number of banks increased from 10 in 1988 (Bawumia, [7]) to 29 in January 2013 (Quartey and Afful-Mensah, [8]) with both Ghanaian and foreign ownership. Additionally, Bawumia, [7] noted that the total asset of banks grew from $0.31 \%$ of GDP to $0.66 \%$ by 2008 , indicating an expanded banking sector compared to the pre-reform era. He further indicated the significant enhancement in other important indicators including capital adequacy, deposit mobilisation, sectoral credit allocation, and interest rate liberalisation. For instance, private sector credit outstripped credit to the public sector for at least a decade: given an average rate of 3.12\% from 1981 to 1990 , private sector credit increased to $15.71 \%$ in 2010 . Standard financial development proxies have also signified improvements in the financial sector over the past decade following the reforms. Broad money supply (\%GDP) increased from an average of $16.50 \%$ (1981-1990) to $31.5 \%$ (2001-2005) and to $29.79 \%$ in 2010. Although real bank lending rate immediately registered positive values: $9.1 \%$ in 1989 to $22 \%$ in 2000 and $9.1 \%$ between 2001 and 2008, real interest rates did not immediately register positive values averaging: $-10 \%$ for 1988 to 2000 and $-8.8 \%$ for 2000 to 2008 . It is noteworthy to say that non-performing loans (NFLs) remain an important problem (Bawumia, [7]). This resulted in a wide interest spread, posing a challenge to stakeholders (Adu et al., [9]). Economic 
growth rates have also seen significant upward adjustments. Real GDP growth increased from an average 2.28\% (1981-1990) to $8.01 \%$ in 2010 (Adu et al., [9]).

Regardless of these empirical facts, the studies from Ghana on the financegrowth hypothesis have tended to generate conflicting results. For example, Sackey and Nkrumah [10] and Adusei [11] both used broad money (\%GDP) and found a positive and negative association respectively between finance and growth of the economy. In addition, most of the studies have only established the association between finance and performance of the economy without going further to determine causal direction between the two variables (Kargbo and Adamu, [12]; Sackey and Nkrumah, [10]; Adu et al., [9]). Yet, the financegrowth causal direction is important because identifying relevant growth-inducing financial sector variables through empirical evidence may be ideal for effective economic policy formulation (Simwaka et al., [13]).

In view of the highlighted gaps, this study aims to investigate whether amelioration of the financial sector has been good for the growth of the Ghanaian economy and also to test the causal direction between the development of the financial system and growth of the economy in Ghana.

The rest of the paper is structured as follows: Section two considers the review of related literature; Section three presents the study methodology; Section four discusses and analyses the empirical results and Section five focuses on the conclusion and policy implications.

\section{Review of Related Literature}

A number of authors have dealt with the relationship between financial development and economic growth. Some of the literature on the subject matter incorporated different measures as proxies for financial development in analysing the relationship between financial development and economic growth while others have tested the relationship through the normal bivariate causality analysis. The studies reviewed are cases carried out in different economies.

Levine et al. [14] applied double approach: 1) Generalized method of moments (GMM) dynamic panel estimators and 2) Cross-sectional instrumental variable estimator, to examine the finance-growth nexus for 71 countries from 1960 to 1995 . Employing financial improvement measures like liquid liabilities (\%GDP), assets of deposit money banks as a share of assets of deposit money banks plus central bank domestic assets, and credit given to private enterprises (\%GDP), they found the presence of a positive finance-growth link, after taking care of possible biases caused by simultaneity, omitted variables, and unobserved country-specific effects.

From Turkey, Kar and Pentecost [15] assessed the causal nexus between the development of the financial system and growth of the economy from 1963 to 1995. Using five different measures to depict the development of the financial structure, they applied Granger causality test within cointegration and vector error correction approach. The study indicated that the causal pattern depends on the indicator used for enhancement of the financial system. To illustrate, 
while broad money (\%GDP) produces results in favour of the finance-led growth hypothesis, bank deposit, private credit, and domestic credit as (\%GDP) provide support for the growth-led finance hypothesis. Hence, they concluded that on the whole the growth-led finance view appears to dominate in Turkey.

Using quarterly time series data on Australia from 1960-1999 period, Thangavelu and James [16] also examined the finance-growth relationship. Applying the VAR model and Granger causality test, they indicated that growth of the economy brings about enhancement in the financial sector once private credit (\%GDP) and bank deposits, defined as M2 minus M1 (\%GDP) were used as indices for the evolution of the financial sector. They showed that development of the financial sector leads to the growth of the economy when equities turnover to GDP was used. No evidence, however, was adduced in support of the bi-directional hypothesis.

The finance-growth relationship has also been looked at in the African context. In a study that examined the finance-growth hypothesis in 41 developing countries from Africa and elsewhere over the 1960-1993 period, Xu [17] adopted a multivariate vector autoregressive (VAR) method whiles using bank deposit (defined as M2 minus currency) as the measure for financial development. The study reported convincing results to confirm the notion that development of the financial sub-sector is crucial for the growth of an economy.

Abu-Bader and Abu-Qarn [18] analysed the causal nexus of the financegrowth phenomenon in Egypt from 1960-2001 by using investment as a third variable. Adopting money stock (\% GDP)-M2Y, and bank deposit liabilities (\% GDP)-LQMY among others as indicators for the development of the financial structure, and implementing Granger causality test by applying the cointegration and VECM framework, they found strong support for the bi-directional hypothesis. Additionally, they indicated that though M2Y impacts on the growth of the economy solely via boosting the amount of investment resources, LQMY affects the growth of the economy by expanding the amount of investment resources or improving the efficiency of investment.

Simwaka et al. [13] also examined the finance-growth nexus in Malawi during the period of 1980-2010. The authors used credit to private sector (\%GDP), bank deposits (\%GDP), and credit to private sector to domestic credit ratio as measures for the evolution of the financial system while implementing ARDL approach and Granger causality tests. Findings from the study showed the presence of long-term positive and significant finance-growth nexus. The Granger causality test demonstrated support for the growth-led finance hypothesis. This was true for all the financial development indicators except for bank deposit (\%GDP). Conversely, the study found no support for the finance-led growth and bi-directional hypotheses. In addition, the association between bank deposits (\%GDP) and growth of the economy was found to be weak.

In Ghana, limited studies have looked at the finance-growth connection. For instance, Esso [19] also investigated the cointegration and causal association of enhancement of the financial sub-sector and growth of the economy in 
ECOWAS economies from 1960-2005. Using M2 (\%GDP) and applying ARDL as well as the non-causality test by Toda and Yamamoto [20], the study exhibited positive finance-growth correlation in the long-run for Ghana, Cape Verde, Cote d'Ivoire, Guinea, and Liberia. Additionally, the causality tests indicated that finance drives economic performance in Ghana, Liberia and Mali while economic performance drives finance in Cote d'Ivoire. Yet, the two variables tend to drive each other in Cape Verde and Sierra Leone. Thus, as the author concluded, the finance-growth relationship is incapable of being generalised across countries since the relationship is country specific.

Quartey and Prah [21] investigated the finance-growth causal link in Ghana. They reported some support for the notion that growth of the economy drives enhancement in the financial sector, once growth of broad money (\%GDP) was employed as a proxy for the development of the financial sub-division. They, however, found the absence of finance driving economic performance or the reverse once growth in domestic credit (\%GDP), credit to private sector (\%GDP), and credit to private sector as a percentage of domestic credit ratio as financial development indices. Lastly, the study found no statistical support for the stages of development hypothesis in Ghana.

In another study that used quarterly data for the 2000-2009 periods, Sackey and Nkrumah [10] looked at the finance-growth connection in Ghana. Applying Johansen cointegration technique in a bivariate vector autoregressive model, the authors concluded that improvement in the financial sector represented by broad money (\%GDP) has a positive relationship with economic growth in Ghana.

Again, Adu et al. [9] assessed the connection between financial sector improvement and growth of the economy from 1961 to 2010. Using eight various indices for the evolution of the finance and applying ARDL approach, they demonstrated that the impact of enhancement of the financial sector is contingent on the indicator used. For example, while credit to private sector (\%GDP) or credit to private sector as a percent of overall credit as measures for the evolution of the financial sector showed a significant positive impact on growth, broad money (\%GDP) indicated a significant negative effect on growth.

Also, Adusei [11] utilised Fully-Modified Ordinary Least Squares (FMOLS), Error Correction Method (ECM) and the GMM approaches to test the financegrowth relationship in Ghana from 1971 to 2010. Using domestic credit (\%GDP)DCY, credit to private sector (\%GDP)-CPY, and broad money (\% GDP)-MY as measures of evolution of the financial sub-sector, it was found that whereas DCY and MY showed negative statistically significant relationships with growth, CPY indicated positive but statistically insignificant association with growth of the economy. Hence, the author declared that improvements in the financial sector hinder the growth of the Ghanaian economy.

A synthesis of the review on the finance-growth empirical literature suggests that the studies from African countries such as Ghana have tended to produce conflicting results. For example, although Sackey and Nkrumah [10] and Adusei 
[11] both used broad money (\%GDP), they found a positive and negative association respectively between finance and economic performance. In addition, the finance-growth studies from Ghana have rarely used domestic deposit, defined as M2-M1 (\%GDP) to denote evolution of the finance sub-sector. Yet, as Kar and Pentecost [15] and Adu et al. [9] have shown, the impact of finance on the growth of the economy is contingent on the choice of measures. Therefore, this study forms part of general efforts to bring more certainty to the finance-growth relationship.

\section{Study Methodology}

\subsection{Model Specification}

Following Simwaka et al. [13], and Sehrawat and Giri [22], the study specified the general finance-growth nexus as:

$$
\mathrm{RGDPPC}_{t}=\beta_{0}+\beta_{1} \mathrm{DD}_{t}+\beta_{2} \mathrm{DCPS}_{t}+\beta_{3} \mathrm{INV}_{t}+\beta_{4} \mathrm{PG}_{t}+\beta_{5} \mathrm{TO}_{t}+\beta_{6} \mathrm{GS}_{t}+\varepsilon_{t}
$$

where RGDPPC represents real gross domestic product per capita which is proxied for economic growth, DCPS represents domestic credit to private sector, DD denotes domestic deposit, INV is investment which is proxied for gross capital formation; PG is the annual growth rate of population; TO indicates trade openness, and GS also represents government spending. $\varepsilon_{t}$ and $t$ represent error term and time respectively.

\subsection{Data Sources and Expected Signs}

The study used annual time series data for six variables over the period of 1970 to 2013. With the exception of real output and population growth, all the variables were expressed as a percentage of GDP. On account of theoretical and empirical literature reviewed, the variables used for the study are described in Table 1.

Table 1. Data sources and expected signs.

\begin{tabular}{|c|c|c|c|}
\hline Variable & Empirics & Data Source & Expected Signs \\
\hline RGDPPC & Al-Yousif [23], Nguyen et al. [24] & WDI & \\
\hline $\mathrm{DD}$ & $\begin{array}{c}\mathrm{Xu}[17], \text { and Abu-Bader and } \\
\text { Abu-Qarn [18] }\end{array}$ & WDI & Positive \\
\hline DCPS & $\begin{array}{l}\text { King and Levine [25], } \\
\text { Madichie et al. [26] }\end{array}$ & WDI & Positive \\
\hline INV & Mankiw et al. [27] & WDI & Positive \\
\hline PG & Mankiw et al. [27] & WDI & Negative \\
\hline TO & $\begin{array}{c}\text { Harrison [28], Onafowora and Owoye } \\
\text { [29], Yanikkaya [30], Yucel [31], } \\
\text { Narayan and Narayan [32] }\end{array}$ & WDI & Positive \\
\hline GS & Mankiw and Scarth [33] & WDI & Positive \\
\hline
\end{tabular}




\subsection{Estimation Techniques}

\subsubsection{Cointegration with ARDL}

Although the ARDL technique involves no initial testing for unit roots, it is imperative to determine that none of the variables is integrated of order two. The ARDL is invalidated in situations where I(2) variables are used (Goswami andHossain, [34]). Consequently, prior to implementing the co-integration analysis, the study adopted the Augmented Dickey-Fuller (ADF) test to examine the stationarity properties of the variables (see Adusei, [35]).

The study used Autoregressive Distributive Lag (ARDL) Bounds test to cointegration advanced by Pesaran and Shin [36], and Pesaran et al. [37] to estimate Equation (1). This is because the ARDL exhibits some attractive econometric benefits. First, it involves no pre-testing for unit roots of variables before use. Second, it is applicable whether the variables in question are integrated of order one or order two or both but not order two. Finally, it is more suitable for a relatively small data sample (Grullon, [38]) which can be likened to what we have in this study.

When the cointegrating nexus is established, the long-term and error correction estimates of the ARDL model are obtained. Therefore, a conditional ARDL model of order $\left(m, n^{1}, n^{2}, n^{3}, n^{4}, n^{5}\right)$ is employed to determine the long-term relationship of the variables of interest. The long-term ARDL model was expressed as:

$$
\begin{aligned}
\operatorname{RGDPPC}_{t}= & \beta_{0}+\sum_{i=1}^{m} \gamma_{1 i} \mathrm{DD}_{t-i}+\sum_{i=1}^{n^{1}} \gamma_{2 i} \mathrm{DCPS}_{t-i}+\sum_{i=1}^{n^{2}} \gamma_{3 i} \mathrm{INV}_{t-i} \\
& +\sum_{i=1}^{n^{3}} \gamma_{4 i} \mathrm{PG}_{t-i}+\sum_{i=1}^{n^{4}} \gamma_{5 i} \mathrm{TO}_{t-i}+\sum_{i=1}^{n^{5}} \gamma_{6 i} \mathrm{GS}_{t-i}+\varepsilon_{t}
\end{aligned}
$$

The short-term dynamics were captured by the error correction model as follows:

$$
\begin{aligned}
\Delta \operatorname{RGDPPC}_{t}= & \beta_{0}+\sum_{i=1}^{m} \delta_{1 i} \Delta \mathrm{DD}_{t-i}+\sum_{i=1}^{n^{1}} \delta_{2 i} \Delta \mathrm{DCPS}_{t-i}+\sum_{i=1}^{n^{2}} \delta_{3 i} \Delta \mathrm{INV}_{t-i} \\
& +\sum_{i=1}^{n^{3}} \delta_{4 i} \Delta \mathrm{PG}_{t-i}+\sum_{i=1}^{n^{4}} \delta_{5 i} \Delta \mathrm{TO}_{t-i}+\sum_{i=1}^{n^{5}} \delta_{6 i} \Delta \mathrm{GS}_{t-i}+\theta \mathrm{ECM}_{t-i}+\varepsilon_{t}
\end{aligned}
$$

where all variables remain as formerly stated; $\theta$ measures the speed of adjustment parameter and its coefficient should ordinarily be negative and significant statistically to give an additional confirmation to the presence of a cointegrating nexus. Finally, ECM is the error correction term.

\subsubsection{Test for Causality}

According to Engle and Granger [39] where two or more variables are I(1) and also cointegrated, it can be concluded that there exist a causal nexus in a certain direction at least. As such, subsequent to establishing the order of integration and cointegration, the study established the finance-growth causal direction by employing the Engle-Granger causality technique. This approach was selected due to its superior robustness in dealing with both large and small samples [40]. 
The causality test based on an error correction model (ECM) was specified as follows:

$$
\begin{gathered}
\Delta \mathrm{RGDPPC}_{t}=\alpha_{1 t}+\sum_{k=1}^{v} \beta_{t} \Delta \mathrm{RGDPPC}_{t-k}+\sum_{k=1}^{v} \varphi_{t} \Delta \mathrm{FD}_{t-k}+\gamma_{t} \mathrm{ECT}_{t-1}+\varepsilon_{t} \\
\Delta \mathrm{FD}_{t}=\alpha_{1 t}+\sum_{k=1}^{v} \beta_{t} \Delta \mathrm{FD}_{t-k}+\sum_{k=1}^{v} \varphi_{t} \Delta \mathrm{RGDPPC}_{t-k}+\gamma_{t} \mathrm{ECT}_{t-1}+\varepsilon_{t}
\end{gathered}
$$

where RGDPPC remains as formerly stated; FD = Financial Development Indicators; $\Delta=$ first differences; $k=1 \cdots v$ is the optimal length of lag determined by Schwarz information criteria; $\mathrm{ECT}_{t-1}=$ the estimated lagged error correction term obtained from the cointegrating relationship of Equation (2). $\beta, \varphi, \gamma=$ the adjustment coefficients, and $\varepsilon_{t}=$ the disturbance term expected to have no correlation with zero means.

The decision rule for the Engle-Granger causality test is that the null hypothesis is rejected where the $p$-value of the computed $F$-statistic is less than $10 \%, 5 \%$, or $1 \%$.

\section{Empirical Results and Analysis}

\subsection{Test for Stationarity}

The Augmented Dickey-Fuller (ADF) test was used to examine the stationarity of the variables used in the study. The results are shown in Table 2.

From Table 2, the Augmented Dickey-Fuller method reported that population growth is stationary at the level, hence integrated of order zero; $\mathrm{I}(0)$. Whilst real gross domestic product per capita, domestic deposit, domestic credit to the

\begin{tabular}{|c|c|c|c|}
\hline Variable & Constant & Constant and Trend & Decision \\
\hline \multicolumn{4}{|c|}{ Level } \\
\hline RGDPPC & 0.5200 & -0.8594 & Series is not stationary \\
\hline $\mathrm{DD}$ & -0.6727 & -2.0691 & Series is not stationary \\
\hline DCPS & -1.5001 & -2.1481 & Series is not stationary \\
\hline INV & -1.3062 & -2.7456 & Series is not stationary \\
\hline PG & $-4.7609^{* * *}$ & $-4.2821^{\star * *}$ & Series is stationary \\
\hline TO & -1.5293 & -2.5289 & Series is not stationary \\
\hline GS & 0.5200 & -3.1706 & Series is not stationary \\
\hline \multicolumn{4}{|c|}{ First difference } \\
\hline RGDPPC & $-4.0501^{\star * *}$ & $-5.8325^{\star * *}$ & Series is stationary \\
\hline $\mathrm{DD}$ & $-5.9817^{\star * *}$ & $-6.4305^{\star * *}$ & Series is stationary \\
\hline DCPS & $-5.4906^{* * *}$ & $-5.4738^{\star * *}$ & Series is stationary \\
\hline INV & $-5.8616^{\star * *}$ & $-5.6806^{\star * *}$ & Series is stationary \\
\hline $\mathrm{TO}$ & $-4.8677^{\star * *}$ & $-4.8337^{\star * *}$ & Series is stationary \\
\hline GS & $-5.5561^{\star * *}$ & $-5.5729^{\star \star *}$ & Series is stationary \\
\hline
\end{tabular}

Table 2. Unit root test using ADF.

Note: ${ }^{* *}$ represents $1 \%$ significance level. 
private sector, investment, trade openness, and government spending were confirmed stationary at the first difference, thus integrated of order one; I(1). The study, therefore, found it appropriate to estimate the model using ARDL Bounds test specification as the series are integrated of orders zero and one.

\subsection{Test for Cointegration}

The ARDL Bounds test procedure was used in determining long-run relationship among the variables employed in the study. The results are presented in Table 3.

The results indicated that the F-statistic is 8.590519, and it turned out to be obviously larger than the $1 \%$ upper bound critical value of 4.39 . Accordingly, there is a finance-growth cointegration, suggesting a long-run finance-growth nexus prevails in Ghana. This conclusion appears consistent with those of Simwaka et al. [13] and Adu et al. [9].

\subsection{The Long Run Results}

The results for the long run relationship are reported in Table 4.

The study proxied domestic credit to private sector and domestic deposit as financial development indicators. It was evident from the results in Table 4 that domestic credit to private sector has significant positive influence on the growth rate of the economy in the long run. This implies that $1 \%$ increase in the amount of financial resources granted to private enterprises results in $0.84 \%$ rise in economic growth. This means that credit availability to the private sector through credit rationing among other policies over the years has resulted in a rise in the growth rate of the economy. This result corroborates the findings of Levine et al.

Table 3. ARDL bounds test results for cointegration relationship.

\begin{tabular}{ccccc}
\hline F-Statistic & $\begin{array}{c}\text { Level of } \\
\text { Significance }\end{array}$ & Lower Bound & Upper Bound & Decision \\
\hline \multirow{2}{*}{8.590519} & $10 \%$ & 2.33 & 3.25 & Evidence of \\
& $5 \%$ & 2.63 & 3.62 & Cointegration \\
\hline
\end{tabular}

Table 4. Estimated ARDL long run coefficients.

\begin{tabular}{ccccc}
\hline \multicolumn{5}{c}{ Dependent variable: RGDPPC } \\
\hline Variable & Coefficient & Std. Error & T-Statistic & Prob. \\
\hline DCPS & 0.8403 & 0.2840 & 2.9583 & 0.0067 \\
DD & -0.9883 & 0.5133 & -1.9254 & 0.0656 \\
INV & -0.6025 & 0.2120 & -2.8417 & 0.0088 \\
PG & -0.6018 & 0.3640 & -1.6532 & 0.1108 \\
TO & -0.1020 & 0.1313 & -0.7768 & 0.4446 \\
GS & 1.1286 & 0.3189 & 3.5391 & 0.0016 \\
@TREND & 0.0077 & 0.0024 & 3.2405 & 0.0034 \\
\hline
\end{tabular}


[14], and Adu et al. [9].

In the other vein, the domestic deposit was found to relate negatively to economic growth and it was statistically significant. Particularly, a $1 \%$ rise in the domestic deposit is accompanied by about $0.99 \%$ decline in long-term growth of the economy. Thus, surprisingly the long-term development of the financial sector shown by an increase in deposits rather tends to shrink the growth of the economy. This implies that deposits in the economy have not been adequately enough to propel economic growth. This finding contradicts that of $\mathrm{Xu}$ [17].

The study revealed that two out of the four control variables proved to be robust and weak determinants of long-run growth of the economy. As demonstrated by the results, population growth has a negative impact on the growth rate of the economy in the long-term, in spite of it being statistically insignificant. A similar was found by Mankiw et al. [27] except that in this study population growth appears to be weak in determining long-run growth.

Similarly, trade openness was deleterious to economic growth, but it was found to be statistically insignificant. This means that trade with the rest of world has adversely affected the long-run growth of the Ghanaian economy. This is not surprising since the country has become a net importer. This evidence contradicts the classical argument on comparative advantage trade and findings of Yanikkaya [30] and Yucel [31] who found a positive relationship between trade openness and growth.

In spite of this, investment as a percentage of GDP exhibited negative and statistically significant long-term effect on the growth of the economy. With the coefficient of -0.6025 , it means that an increase in investment by $1 \%$ will bring about $0.60 \%$ decline in growth of the economy. This contradicts the evidence shown by Mankiw et al. [27].

Also, in the case of government spending as a percentage of GDP, the result was positive and statistically significant. The study then realised that $1 \%$ increase in government spending will lead to $1.13 \%$ rise in economic growth. This finding is confirmed by Mankiw and Scarth [33].

\subsection{The Short Run Results}

The results of short-term effects of financial development as well as the control variables on economic growth in Ghana are summarised in Table 5.

With respect to the short run relationships, the nexus relative to domestic credit to private sector and growth of the economy was positive and statistically significant at $5 \%$. It particularly indicates that a $1 \%$ rise in the credit given to private enterprises is accompanied by about $0.05 \%$ expansion in the Ghanaian economy. The finding is similar to what was observed in the long-run period and may suggest that Ghanaian financial institutions offer relatively effective intermediary services which induce greater investment efficiency of private enterprises, thereby impacting on growth positively. This confirms the finding of Adu et al. [9] but contradicts that of Adusei [11]. For example, Adusei [11] reports that the nexus for credit given to the private sector and growth of the economy in Ghana is 
Table 5. Estimated ARDL short run coefficients and the error correction estimate.

\begin{tabular}{ccccc}
\hline \multicolumn{4}{c}{ Dependent variable: RGDPPC } \\
\hline Variable & Coefficient & Std. Error & T-Statistic & Prob. \\
\hline $\mathrm{D}(\mathrm{DCPS})$ & 0.0514 & 0.0206 & 2.4923 & 0.0197 \\
$\mathrm{D}(\mathrm{DCPS}(-1))$ & -0.1348 & 0.0228 & -5.9209 & 0.0000 \\
$\mathrm{D}(\mathrm{DD})$ & -0.1513 & 0.0282 & -5.3638 & 0.0000 \\
$\mathrm{D}(\mathrm{DD}(-1))$ & 0.1084 & 0.0275 & 3.9378 & 0.0006 \\
$\mathrm{D}(\mathrm{INV})$ & 0.0049 & 0.0184 & 0.2655 & 0.7928 \\
$\mathrm{D}(\mathrm{INV}(-1))$ & 0.1013 & 0.0214 & 4.7232 & 0.0001 \\
$\mathrm{D}(\mathrm{PG})$ & -0.1594 & 0.0537 & -2.9709 & 0.0065 \\
$\mathrm{D}(\mathrm{TO})$ & -0.0377 & 0.0219 & -1.7245 & 0.0970 \\
$\mathrm{D}(\mathrm{GS})$ & 0.1601 & 0.0323 & 4.9584 & 0.0000 \\
$\mathrm{D}(\mathrm{GS}(-1))$ & -0.1029 & 0.0342 & -3.0043 & 0.0060 \\
$\mathrm{C}$ & 0.6361 & 0.0611 & 10.4073 & 0.0000 \\
CointEq(-1) & -0.2329 & 0.0225 & -10.3520 & 0.0000 \\
\hline
\end{tabular}

Cointeq $=$ RGDPPC $-\left(0.8403^{*} \mathrm{DCPS}-0.9883^{*} \mathrm{DD}-0.6025^{*} \mathrm{INV}-0.6018^{*} \mathrm{PG}-0.1020^{*} \mathrm{TO}+\right.$ $\left.1.1286^{*} \mathrm{GS}+0.0077^{*} @ \mathrm{TREND}\right)$.

positive but statistically insignificant.

On the other hand, domestic deposit showed a statistically significant negative association with the growth of the economy at $1 \%$ significance level. This conforms to the phenomenon in the long-run. It specifically demonstrates that a $1 \%$ increase in the deposit is accompanied by about $0.15 \%$ reduction in economic growth. This seems at variance with the intuitive position that higher deposit should lead to more lending and thus exert positive effects on growth. Given this, a plausible explanation for the finding then may be that the production and consumption systems of the Ghanaian economy are hugely dependent on imports, making deposit given out as credit end up financing imports which act as a leakage in the national accounting system. This conclusion contradicts the finding of Simwaka et al. [13] where they demonstrate the finance-growth association to be weak in Malawi.

Among the four control variables involved in this study, investment as a percentage of GDP was found to relate directly to economic growth but it was statistically insignificant in short run. This suggests that in the short-term, investment is not robust in determining the growth of the Ghanaian economy. The study contradicts result of Mankiw et al. [27].

Also, the population growth still preserved its negative relationship with economic growth but it is significant in the short-run. Given its coefficient of -0.1594 , it implies $1 \%$ boost in population growth is matched by approximately $0.16 \%$ decrease in economic growth. This is at odds with the long-run finding for this study but it is consistent with the finding of Mankiw et al. [27].

Unlike the long run results, the coefficient of trade openness showed a significant negative impact on economic growth. This implies that higher trade with the world has declining growth implications for Ghana. The result controverts 
the classical argument on comparative advantage trade and the findings of Yanikkaya [30] and Yucel [31].

Turning all attention on the impact of government spending on economic growth, the result showed a statistically significant positive relationship between government spending and economic growth. In specific terms, $1 \%$ increase in government spending in the short-run is associated with $0.16 \%$ increase in economic growth. This finding falls in line with the long-run occurrence and it confirms the finding of Mankiw and Scarth [33]. It was also found that an increase in government spending a year ago leads to decline in economic growth in the current period.

The result of the error correcting model (ECM) indicates an adjustment to the equilibrium state after a shock. The lagged error term coefficient is negative $(-0.232888)$, as required and is strongly significant at $1 \%$ level. This serves to further affirm the presence of long-run finance-growth nexus. Again, it suggests that about $23 \%$ of distortions created by shocks in the preceding year can be restored in the current year.

\subsection{Test for Granger Causality}

Having established that more than two of the variables are I(1) and cointegrated; it indicates that a causal relationship exists in one direction (Engle and Granger, [39]). The study, therefore, conducted Granger causality test to ascertain the direction of the causal relationship between economic growth and financial development indicators proxied by domestic credit to private sector, and domestic deposit. Table 6 displays the results of the Granger causality test.

From Table 6, it was evident that the null hypothesis that changes in domestic credit to private sector do not Granger cause variations in economic growth was rejected at $5 \%$ significance level. This implies that changes in domestic credit to private sector explain the variations in the growth rate of the Ghanaian economy. The same observation was made with domestic credit to private sector as the endogenous variable. The null hypothesis of no causality running from economic growth was accepted at any of the significance levels. This means that changes in economic growth do not explain the changes in domestic credit to private sector.

From the analysis of the results, there is a dependence of the Ghanaian economy to the changes in domestic credit to the private sector at $5 \%$ level of significance. Therefore, there is a uni-directional relationship between domestic credit to private sector and economic growth in Ghana. This conclusion corroborates

Table 6. Results of the granger causality test.

\begin{tabular}{cccc}
\hline Null Hypothesis: & Obs & F-Statistic & Prob. \\
\hline DCPS does not Granger cause RGDPPC & 42 & 3.93828 & 0.0281 \\
RGDPPC does not Granger cause DCPS & & 1.76381 & 0.1855 \\
DD does not Granger cause RGDPPC & & 0.00818 & 0.9919 \\
RGDPPC does not Granger cause DD & & 6.06412 & 0.0053 \\
\hline
\end{tabular}


that of Levine et al. [14] but contradicts those of Kar and Pentecost [15], Thangavelu and James [16], Quartey and Prah [21], and Simwaka et al. [13].

Also, the study indicated that changes in domestic deposit do not Granger cause variations in economic growth. However, the study failed to discard the null hypothesis that economic growth does not Granger cause domestic deposit at $1 \%$ significance level. This means that there is a uni-directional causality running from the variations in economic growth to the domestic deposit in Ghana. The result is similar to the findings of Kar and Pentecost [15], and Thangavelu and James [16] but contradicts those of Abu-Bader and Abu-Qarn [18], Quartey and Prah [21], and Simwaka et al. [13].

On the basis of the reported results, the study abandoned the null hypothesis in favour of the alternative hypothesis that there is a causal link between the development of the financial sector and growth of the economy. In particular, both the finance-led and growth-led finance hypotheses prevail in Ghana.

\section{Conclusion and Policy Implications}

Although the finance-growth relationship has been looked at in African countries such as Ghana, the outcomes have been mixed while the causal direction between the two variables has particularly not been examined. The study, therefore, applied ARDL approach and Granger causality test to investigating the relationship and the causal direction between financial development and economic growth in Ghana during the period 1970-2013. It was found that the amount of credit from domestic sources given to the private sector maintained a positively significant nexus with the growth of the economy through the short and long run periods whereas the domestic deposit did the inverse across the short and long-run periods.

Also, the results established that there is a dependence of the Ghanaian economy to the changes in domestic credit to private sector whilst there exists a uni-directional causality running from the variations in economic growth to the domestic deposit in Ghana. In essence, both the finance-led and growth-led hypotheses have been shown to be present in Ghana.

Consistent with the findings, it is recommended that the authorities concentrate on improving the efficiency of the financial system to allow deposits to be channelled to growth-inducing investments to bring about the long-term growth of the economy.

Furthermore, owing to the fact that this study used only two measures for financial development, and yet most Ghanaian studies have not examined the causal dimension of the finance-growth relationship (for example, Sackey and Nkrumah, [10]), succeeding studies should employ other indices for financial development to particularly investigate the finance-growth causal direction dimension in Ghana.

\section{References}

[1] Schumpeter, J.A. (1912) Theorie der wirtschaftlichen Entwicklung. Dunker \& Humblot, Leipzig. The Theory of Economic Development Translated by R. Opie. 
Harvard University Press, Cambridge, MA, 1934.

[2] Levine, R. (1997) Financial Development and Economic Growth: Views and Agenda. Journal of Economic Literature, 35, 688-726.

[3] McKinnon, R. (1973) Money and Capital in Economic Development. The Brooking Institute, Washington DC.

[4] Shaw, E.S. (1973) Financial Deepening in Economic Development. Oxford University Press, London.

[5] La Porta, R., Lopez-de-Silanes, F. and Shleifer, A. (2002) Government Ownership of Commercial Banks. Journal of Finance, 57, 471-517.

https://doi.org/10.1111/1540-6261.00422

[6] Aryeetey, E., Nissanke, M. and Steel, W.F. (2000) Intervention and Liberalization: Changing Policies and Performance in the Financial Sector. In: Aryeetey, E., Harrigane, J. and Nissanke, M., Eds., Economic Reforms in Ghana: The Miracle and the Mirage, James Currey and Woeli Publishers, Oxford.

[7] Bawumia, M. (2010) Monetary Policy and Financial Sector Reform in Africa: Ghana's Experience. Combert Impressions Ghana Ltd., Accra.

[8] Quartey, P. and Afful-Mensah, G. (2014) Financial and Monetary Policies in Ghana: A Review of Recent Trends. Review of Development Finance, 4, 115-125.

https://doi.org/10.1016/j.rdf.2014.07.001

[9] Adu, G., Marbuah, G. and Mensah, J.T. (2013) Financial Development and Economic Growth in Ghana: Does the Measure of Financial Development Matter? Review of Development Finance, 3, 192-203. https://doi.org/10.1016/j.rdf.2013.11.001

[10] Sackey, F.G. and Nkrumah, E.M. (2012) Financial Sector Deepening and Economic Growth. Journal of Economics and Sustainable Development, 3, 122-139.

[11] Adusei, M. (2013) Financial Development and Economic Growth: Evidence from Ghana. The International Journal of Business and Finance Research, 7, 61-76.

[12] Kargbo, S.M. and Adamu, P.A. (2009) Financial Development and Economic Growth in Sierra Leone. Journal of Monetary and Economic Integration, 9, 30-61.

[13] Simwaka, K., Munthali, T., Chuimia, A. and Kabanga, G. (2012) Financial Development and Economic Growth in Malawi: An Empirical Analysis. Banks and Bank System, 7, 85-96.

[14] Beck, T., Levine, R. and Loayza, N. (2000) Finance and the Sources of Growth. Journal of Financial Economics, 58, 261-300. https://doi.org/10.1016/S0304-405X(00)00072-6

[15] Kar, M. and Pentecost, E.J. (2000) Financial Development and Economic Growth in Turkey: Further Evidence on the Causality Issue. Economic Research Paper 27.

[16] Thangavelu, S.M. and James, A.B.J. (2004) Financial Development and Economic Growth in Australia. Empirical Economics, 29, 247-260. https://doi.org/10.1007/s00181-003-0163-7

[17] Xu, Z. (2000) Financial Development, Investment, and Economic Growth. Economic Inquiry, 38, 331-344. https://doi.org/10.1111/j.1465-7295.2000.tb00021.x

[18] Abu-Bader, S. and Abu-Qarn, A.S. (2008) Financial Development and Economic Growth: The Egyptian Experience. Journal of Journal of Policy Modelling, 30, 887898. https://doi.org/10.1016/j.jpolmod.2007.02.001

[19] Esso, L.J. (2010) Cointegrating and Causal Relationship between Financial Development and Economic Growth in ECOWAS Countries. Journal of Economics and International Finance, 2, 036-048. 
[20] Toda, H.Y. and Yamamoto, T. (1995) Statistical Inference in Vector Autoregressions with Possibly Integrated Processes. Journal of Econometrics, 66, 225-250. https://doi.org/10.1016/0304-4076(94)01616-8

[21] Quartey, P. and Prah, F. (2008) Financial Development and Economic Growth in Ghana: Is There a Causal Link? The African Finance Journal, 10, 28-54.

[22] Sehrawat, M. and Giri, A.K. (2015) Financial Development and Economic Growth: Empirical Evidence from India. Studies in Economics and Finance, 32, 340-356. https://doi.org/10.1108/SEF-10-2013-0152

[23] Al-Yousif, Y.K. (2002) Financial Development and Economic Growth: Another Look at the Evidence from Developing Countries. Review of Financial Economics, 11, 131-150. https://doi.org/10.1016/S1058-3300(02)00039-3

[24] Nguyen, Q.N., Pham, T.M. and Bhar, R. (2014) Foreign Direct Investment and Economic Growth during Financial Liberalization Episodes. International Journal of Economics and Finance, 6, 91. https://doi.org/10.5539/ijef.v6n8p91

[25] King, R.G. and Levine, R. (1993) Finance and Growth: Schumpeter Might Be Right. The Quarterly Journal of Economics, 108, 717-737. https://doi.org/10.2307/2118406

[26] Madichie, C., Maduka, A., Oguanobi, C. and Ekesiobi, C., (2014) Financial Development and Economic Growth in Nigeria: A Reconsideration of Empirical Evidence. Journal of Economics and Sustainable Development, 5, 199-208.

[27] Mankiw, N.G., Romer, D. and Weil, D.N. (1992) A Contribution to the Empirics of Economic Growth. The Quarterly Journal of Economics, 17, 407-437. https://doi.org/10.2307/2118477

[28] Harrison, A. (1996) Openness and Growth: A Time-Series, Cross-Country Analysis for Developing Countries. Journal of development Economics, 48, 419-447. https://doi.org/10.1016/0304-3878(95)00042-9

[29] Onafowora, O.A. and Owoye, O. (1998) Can Trade Liberalization Stimulate Economic Growth in Africa? World Development, 26, 497-506. https://doi.org/10.1016/S0305-750X(97)10058-4

[30] Yanikkaya, H. (2003) Trade Openness and Economic Growth: A Cross-Country Empirical Investigation. Journal of Development Economics, 72, 57-89. https://doi.org/10.1016/S0304-3878(03)00068-3

[31] Yucel, F. (2009) Causal Relationships between Financial Development, Trade Openness and Economic Growth: The Case of Turkey. Journal of Social Sciences, 5 , 33-42. https://doi.org/10.3844/jssp.2009.33.42

[32] Narayan, P.K. and Narayan, S. (2013) The Short-Run Relationship between the Financial System and Economic Growth: New Evidence from Regional Panels. International Review of Financial Analysis, 29, 70-78. https://doi.org/10.1016/j.irfa.2013.03.012

[33] Mankiw, N.G. and Scarth, W. (2008) Macroeconomics. Third Canadian Edition, Worth Publishers, New York.

[34] Goswami, G.G. and Hossain, M.Z. (2013) Testing Black Market vs. Official PPP: A Pooled Mean Group Estimation Approach. The Empirical Economics Letters, 12, 1291-1300.

[35] Adusei, M. (2014) Does Economic Growth Promote Financial Development? Research in Applied Economics, 6, 209-220. https://doi.org/10.5296/rae.v6i2.5106

[36] Pesaran, M.H., Shin, Y. and Smith, R.P. (1999) Pooled Mean Group Estimation of Dynamic Heterogeneous Panels. Journal of the American Statistical Association, 94, 621-634. https://doi.org/10.1080/01621459.1999.10474156 
[37] Pesaran, M.H., Shin, Y.C. and Smith, R. (2001) Bound Testing Approaches to the Analysis of Level Relationships. Journal of Applied Econometrics, 16, 289-326. https://doi.org/10.1002/jae.616

[38] Grullón, S. (2011) The Balance of Payments Constraint as an Explanation of Growth Rate Differences in the Dominican Republic. European Journal of Social Sciences, 25, 386-394.

[39] Engle, R.F. and Granger, C.W.J. (1987) Cointegration and Error Correction Representative, Estimation and Testing. Econometrica, 55, 251-276. https://doi.org/10.2307/1913236

[40] Odhiambo, N.M. (2008) Financial Depth, Savings and Economic Growth in Kenya: A Dynamic Causal Linkage. Economic Modelling, 25, 704-713. https://doi.org/10.1016/j.econmod.2007.10.009

Submit or recommend next manuscript to SCIRP and we will provide best service for you:

Accepting pre-submission inquiries through Email, Facebook, LinkedIn, Twitter, etc. A wide selection of journals (inclusive of 9 subjects, more than 200 journals) Providing 24-hour high-quality service User-friendly online submission system Fair and swift peer-review system Efficient typesetting and proofreading procedure Display of the result of downloads and visits, as well as the number of cited articles Maximum dissemination of your research work

Submit your manuscript at: http://papersubmission.scirp.org/

Or contact me@scirp.org 